\title{
REGULATORY AND LEGAL PROVISION OF THE PROCESS OF DISINFECTION OF GRAIN AT GRAIN PROCESSING FACILITIES
}

\begin{abstract}
The article is devoted to the topical problem of controlling the contamination of grain products with agricultural pests at the facilities of the grain processing industry.

The authors consider the use of one of the most effective methods of disinfection of grain products - fumigation, which, provided it is carried out competently and in a timely manner, avoids unwanted losses of grain and grain products.

The characteristics of the main chemicals that are widely used as fumigants are presented.

The article summarizes fumigants used in advanced countries of the world and are an alternative to the banned methyl bromide.

A brief overview of modern fumigants allowed by the legislation of Ukraine is given, the existing problems of the domestic market of pesticides are revealed.

Given that the effectiveness of fumigation depends on compliance with the technology of fumigation, special attention in the article is paid to the procedure for disinfection of grain products by fumigants.

The authors analyse in detail the regulatory framework of this issue, safety rules, the use of personal protective equipment.

The characteristic features and consequences of harmful effects of fumigants on the human body human body and the environment in the conditions of changing the order of disinfection of grain products are revealed.

All grain processing enterprises have strict safety requirements for fumigation and degassing works.

Training of experienced specialists is one of the important prerequisites for the safety of disinfection, so this article suggests ways to solve the problem of staff training.

Emphasis is placed on the need to improve the regulatory mechanisms for regulating the quality control of both fumigants and fumigation works.
\end{abstract}

Key words: grain processing branch, disinfection, fumigation, fumigants, safety precautions.

\section{Introduction}

To date, there are a number of modern environmentally friendly and safe ways to disinfect food, feed and seed grain, such as heat treatment, microwave treatment, ozonation, etc., in disinfection of grain without the use of hazardous and harmful substances. But the vast majority of grain processing plants and farms continue to use the traditional method of disinfection - fumigation, which is the treatment of grain with gaseous pesticides (fumigants). This is a justified and effective measure that allows you to process large batches of grain products, large volumes and areas of production and storage facilities at once. At the same time, this method is risky, because certain concentrations of toxic substances may remain in the grain after chemical treatment, the grain may be damaged and unsuitable for further processing and use, and the chemical decontamination process itself is dangerous, high-risk work, employees of enterprises and the environment [1].

\section{Formulation of the problem}

In Ukraine, for disinfection of grain with gaseous chemicals (fumigation) use mainly one fumigant from the list of products that are approved for use in the grain processing industry. This is aluminium or magnesium phosphide, which when interacting with moist air or products emits highly toxic gas phosphorus tri-hydride (phosphine). Today it is an effective fumigant, which, except for Ukraine, is used in Europe and almost all countries. Unlike another fumigant, methyl bromide, which was in widespread use in the last century and is now banned in our country and Europe, phosphine is more effective at low concentrations and prolonged exposure as opposed to high concentrations and short exposure to methyl bromide $[2,3]$.

Unfortunately, fumigation is often carried out by non-professionals, untrained performers, which leads to accidents, poisoning during disinfection. The reason for this is trivial - the goal is to save money on experienced professionals - specialists in their field. There are currently organizations in the market for disinfection services that have had their certification revoked. Specialists in grain disinfection are not trained in domestic institutions of higher and secondary special education. Together, all this creates the basis for the provision of lowquality disinfection services by pseudo-specialists and at 
the same time creating a threat of accidents at work, deteriorating product quality and environmental pollution [4].

Goal. The purpose of this work is the analysis of modern chemicals used for disinfection of grain products at grain processing facilities, as well as the study and analysis of existing in Ukraine regulatory and legal support for the organization and conduct of this type of work.

\section{Presenting main material}

The All-Ukrainian State Association "Fumigation Association" - is an association of professionals In Ukraine [5]. First of all, this organization provides methodological assistance - conducts seminars, trainings on pest control for workers in the grain processing industry. After graduation, you can pass an exam in the State Service of Ukraine for Food Safety and Consumer Protection [6], with which the Fumigation Association has concluded an agreement, and obtain a certificate. Thus, any grain processing plant, grain farms, grain traders get the opportunity to disinfect them.

To carry out independent work on disinfection of grain products, the head and specialist of the enterprise will usually involve employees of this enterprise. Therefore, it is necessary to conduct appropriate training on safety when performing work with pesticides [7]. Business leaders should also be familiar with the relevant rules of labour protection, and, above all, with the legal framework, as work with toxic and harmful substances, as well as decontamination, disinsection, deratization and disinfection of premises, are included in the list of highrisk work (НПАОП 0.00-4.12-2005) [8].

A number of grain disinfection works (fumigation, disinsection, deratization and preparation of baits) are carried out at grain processing enterprises and farms for grain cultivation both in production and storage premises, and disinsection of technological and transport equipment, containers. This also includes work on the transportation, reception, storage and release of pesticides; disposal, destruction and disposal of spoiled and obsolete pesticides that are unusable; disposal of personal protective equipment contaminated with chemicals; seed treatment work.

For a long time in Ukraine, the legislation on pesticides was not revised, and changes were made that were unsystematic. In order to regulate relations in the field of pesticide management, a draft Law 2548 "On Amendments to Some Laws of Ukraine on Improving State Regulation in the Field of Pesticide and Agrochemical Management" was developed [9]. There is a ban on the transportation (shipment) of plant protection products to the territory of the country by individuals; stricter requirements for labelling and packaging of agrochemicals, as well as the availability of the State Register of pesticides and agrochemicals permitted for use in Ukraine in the public domain.

The list of pesticides and agrochemicals approved for use in Ukraine today contains a large number of names of drugs for various purposes. Fostoxin, Gaztoxin, Selfos, Alfos, Phosphorus based on aluminium phosphide and Magtoxin based on magnesium phosphide are currently allowed to be used as fumigants for disinfection of grain and grain products in our country, which are able to emit phosphine gas (PH3) in the presence of moisture in the air and at certain temperatures [10]. They are available in various forms: tablets, plates, granules, bags of powder, tapes of bags of powder - sachets, tubes. In the case of aluminium phosphide, phosphine production is usually slow, but magnesium phosphide reacts with humidity and humidity at lower temperatures than aluminium phosphide, and the production of $\mathrm{PH}_{3}$ may be more complete. This property allows efficient fumigation at lower temperatures where it is impossible to use aluminium phosphide.

Phosphine is a highly toxic, colourless, odourless gas that easily penetrates all hard-to-reach areas and effectively kills pests and their larvae. It is poorly adsorbed by grain and grain products, so it is easily removed by degassing [11]. Phosphine belongs to the 1st class of dangers and is a potent poison for humans; its maximum permissible concentration in the air of the working area is $0.1 \mathrm{mg} / \mathrm{m}^{3}$.

At concentrations in the air above $1.79 \%$ phosphine is able to ignite. By mixing phosphine with other gases (carbon dioxide, hydrogen, nitrogen), it can be made non-flammable.

Carbon dioxide has long been used as a fumigant, but it acts very slowly, so its use is impractical. However, a mixture of carbon dioxide with phosphine, which has a three-day exposure period, is now successfully used for fumigation in Europe.

Research is underway into the use of another fumigant, sulphuryl fluoride, to disinfect products and raw materials in the food industry. Developed in the USA, ProFume gas fumigant, based on the action of sulphur fluoride pests, is used in 18 countries around the world for the treatment of premises from which food products are removed. Another sulphur-containing fumigant is carbonyl sulphide, which penetrates well into both flour and other packaged products, but there are difficulties in determining its concentration in the air $[11,12]$.

The above fumigants are currently an alternative to methyl bromide, which has been included in the Montreal Protocol since 1991, because this substance depletes the ozone layer. Many countries have gradually abandoned the use of this fumigant, continuing to search for effective, cost-effective and environmentally friendly substitutes. According to Ukrainian legislation, methyl bromide has not passed the state sanitary-epidemiological examination and is not included in the State Register of pesticides and agrochemicals approved for use in Ukraine as a fumigant in grain enterprises [10, 12].

At the moment in Ukraine there is a problem of quality of drugs for fumigation. According to experts, the domestic market is filled with $25 \%$ of counterfeits, which are in demand at a lower cost. This only leads to a worsening of the situation with the contamination of grain and grain products.

What unites all types of fumigants is that they are all to some extent toxic to the human body. These are poisons that can affect the nervous system, blood vessels, respiratory system, liver, kidneys, causing acute or chronic poisoning and even death. However, signs of poisoning in humans can appear up to 48 hours after the use of fumigants. An extremely serious consequence of poisoning is pulmonary oedema, which can eventually 
lead to suffocation. Due to the high toxicity of fumigants, proper organization of fumigation work and staff training are of great importance.

Execution of all types of these works is carried out in accordance with the requirements of the legislative and regulatory framework of Ukraine, namely: the Law of Ukraine "On Pesticides and Agrochemicals" (1995) [13], the Law of Ukraine "On Plant Protection" (1998) [14] and SSR 8.8.1.2.001-98 State sanitary rules. Transportation, storage and use of pesticides in the national economy[15].

The Law "On Pesticides and Agrochemicals" [13] contains the following requirements:

- Pesticides and agrochemicals of any domestic or foreign manufacturer for their intended purpose must have high biological efficiency; be harmless to humans and the environment when used properly; must comply with certificates, sanitary norms and state standards (Article 4);

- According to sanitary requirements, the safety of all agricultural raw materials must meet the maximum permissible levels of pesticide and agrochemical residues. And those raw materials, that for these reasons cannot be used, are subject to mandatory removal from the processes of processing and storage, disposal and destruction in the prescribed manner (Article 18);

- All operations on transportation, storage, application, utilization, destruction, neutralization of pesticides and agrochemicals, and also trade in them are carried out according to requirements of the current legislation, sanitary rules of transportation, storage and application of pesticides and agrochemicals and other regulations (Article 11);

- Persons engaged in such activities must obtain a permit with a certificate of the right to work with relevant pesticides and agrochemicals. The procedure for obtaining this permit is determined by the government - the Cabinet of Ministers of Ukraine [16]. It is forbidden to involve persons less than 18 years of age, pregnant women, nursing mothers, workers with contraindications due to health conditions in such works. Permits (permitting documents) are issued by phytosanitary inspections on the basis of a certificate (certificate) of special training in safe work with pesticides and agrochemicals and a medical book indicating the medical commission on the absence of health contraindications for such work. The phytoinspection conducts training of ordinary executors of such works once in three years. And for the organizers of these works at the enterprises of advanced training takes place every year at seminars and courses of phytoinspections.

The Law of Ukraine "On Plant Protection" [14] indicates the need for mandatory measures to protect plants by enterprises of all forms of ownership and citizens engaged in processing, storage, sale of plants and plant products. For this purpose, state control is provided (Article 6), one of the main tasks of which is aimed at the timely introduction of prevention and destruction of pests in places of storage of plant products. The law establishes the rights and obligations of enterprises and citizens in the field of plant protection (Article 18):

- Systematic inspection of plant products, storages, etc. In case of detection of the presence and spread of pests to inform the central executive body that implements the state policy in the field of plant protection;

- Timely introduce preventive and extermination measures to control pests;

- Comply with and comply with regulations on storage, transportation and use of plant protection products;

- Apply appropriate technical means, equipment and means of public and individual security.

The Law [14] also stipulates that violators of this legislation are subject to disciplinary, administrative, civil or criminal liability (Article 21). Punishment can occur in cases of:

- Spread of pests due to violation of the technology of storage of plant and other raw materials:

- The spread of pests as a result of untimely implementation of a set of preventive and extermination measures to control pests;

- Lack of special training and appropriate admission and certificate of the right to conduct such work;

- Violation of the order of storage, transportation, use and trade in plant protection products.

At enterprises of all forms of ownership, plant protection works may be performed by employees with appropriate training and only under the direct supervision of plant protection specialists. (Article 24) [14].

State sanitary rules SSR 8.8.1.2.001-98. Transportation, storage and use of pesticides in the national economy [15] are a mandatory part of sanitary legislation for public and private enterprises, farms and persons working with pesticides. Violation of the requirements of this normative document can lead to disciplinary, administrative, civil and criminal liability, because in case of violations of the rules of use can occur poisoning and death, especially people.

SSR 8.8.1.2.001-98 defines a fairly large list of diseases, which is the basis for the ban on disinfection work. These are diseases of the central nervous system, mental disorders, endocrine diseases, oncology, hematopoietic diseases, stage II and III hypertension, pulmonary diseases, active forms of tuberculosis, diseases of the gastrointestinal tract, liver, kidneys, rheumatism, joint diseases, gynaecological diseases, allergic diseases such as bronchial asthma, respiratory diseases, skin diseases, chronic alcoholism, drug addiction, drug addiction, etc.

Only practically healthy workers with mandatory medical examination before disinfection work should be allowed to work with fumigants.

When fumigating premises and equipment, workers should use insulating personal protective equipment for leather or special clothing made of film fabric. Persons responsible for decontamination work must ensure the selection of personal protective equipment and control all workers for compliance with the rules of their use.

Personal protective equipment for disinfection is a set of special protective clothing, appropriate footwear, gloves or mittens, gas masks, respirators, goggles, which is selected individually for each employee and attached to him for the entire period of work. Workers' shoes must be free of iron nails and heels.

For storage of personal protective equipment the individual case in the clean and dry room, with good ventilation, away from storage of pesticides is given. It is 
forbidden to use the set or a separate means of protection after work, to take it home. Appropriate recommendations have been developed for disinfection and neutralization of protective special clothing and respiratory protective equipment $[7,16]$.

Fumigation or aeration is carried out mainly in production and storage facilities. The rules on fumigation work clearly require employees to comply with a number of requirements in order, first and foremost, to preserve their own health, life and the environment, as this procedure is authorized for the use of high-speed highly volatile and toxic substances. Permission for fumigation is issued by local bodies of the State Service of Ukraine for Food Safety and Consumer Protection. The number of people in the team that will perform decontamination work must be at least three.

During the entire disinfection period, from the beginning of the aeration to the end of degassing, the facility must be provided with round-the-clock protection. The entire area around the object to be fumigated is temporarily fenced off, posters and plaques with warning signs about the danger are posted. The room intended for temporary storage of fumigants is also provided with round-the-clock protection. Security guards, as well as workers, are instructed in safety and provided with gas masks.

Due to the fact that a certain number of facilities of grain processing enterprises are located in settlements, it is necessary to pay attention to their location in relation to industrial and residential buildings. It is forbidden to carry out fumigation of grain processing facilities if they are located at a distance of less than $30 \mathrm{~m}$ from industrial, office premises and facilities and railways, as well as less than $50 \mathrm{~m}$ from residential buildings.

Workers who perform fumigation work are involved in round-the-clock rotation on a schedule throughout the time of aeration, exposure and degassing of the object.

Workers who are not involved in fumigation work are removed from the facility and the protection zone before the start of fumigation. Their admission to such zones is prohibited until the end of degassing.

Before starting work, the premises are sealed: windows, cracks, armholes are tightly closed. Equipment, raw materials, finished products are covered with synthetic films or tarpaulins with sufficient gas tightness. At the end of the release of the fumigant, the crew leaves the room and closes the door tightly. Gas masks are removed in safe places.

The crew on duty must monitor the air environment within the facility, the protection zone and at its borders. Indicator tubes are usually used for this purpose. The duty officer also takes the necessary measures in the event of a fumigant leak in order to prevent its spread beyond the boundaries of the protection zones.

All work with pesticides, from their use to destruction, is carried out only during the day. Their end time is no later than 5:00 p.m. Gasification should be planned only in the morning, but not later than 12.00 . Attention is also paid to the temperature of the air outside and inside the object, namely it should be not lower than $+10{ }^{0} \mathrm{C}$, air velocity - not more than $7 \mathrm{~m} / \mathrm{s}$ (from calm to moderate wind). Outside the production and storage fa- cilities it is allowed to carry out spraying work at a wind speed of not more than $3 \mathrm{~m} / \mathrm{s}$.

During fumigation, exposure and the first day of degassing (especially if flammable drugs are used) in order to protect electrical equipment, it is necessary to turn off power and lighting power lines near the warehouses being treated. Power, lighting, signal and telephone cables are de-energized at a distance of $20 \mathrm{~m}$ from the fumigated warehouse. Smoking, lighting matches, and breeding fires are prohibited within the protection zones.

After fumigation, all objects must be completely degassed before they can be used. For large facilities, degassing is carried out gradually in order to prevent the release into the environment of large volumes of spent fumigants. Degassing is usually carried out by active ventilation. In case of lack of mechanical ventilation, a passive method is used - sequential opening of doors and windows. If the density of the fumigant gas is higher than the density of the air, it is necessary to ventilate the basement (if any). At the end of ventilation in the premises close the windows and doors and increase the temperature inside the building or warehouse by $2-3{ }^{0} \mathrm{C}$ higher than during fumigation and after 12-16 hours ventilate the room until the complete disappearance of the smell of fumigant.

Monitoring of the air environment in the protection zone is mandatory during degassing. The purpose of this procedure is to prevent the spread of fumigant outside the protection zone.

In case of accidental contact of liquid fumigants on the floor, walls, ceiling and other places for their treatment, special neutralizing mixtures are used.

Checking the object for complete degassing is performed only during the day, for which they use the methods of analysis recommended for specific fumigants.

Degassing is considered complete and carried out only when the content of fumigant in the wind objects does not exceed the maximum allowable concentration of this fumigant in the air of the working area. If degassing of premises in residential areas has been carried out, then it is necessary to check the content of harmful substances in the air, which should not exceed the appropriate maximum allowable concentration.

The end of degassing is set by the supervisor of these works in a written permit for the use of production or storage facilities.

There are certain requirements for raw materials, finished products and packaging. It is impossible to remove grain and finished products until the smell of fumigants disappears in them. When treating flour and cereals in bags with fostoxin and gastoxin, these preparations and residues formed during their decomposition must not be allowed to get on the surface of the bag container.

During loading and unloading operations with grain, flour, groats that have been subjected to fumigation, it is necessary to take measures to exclude the possibility of poisoning of workers.

Bags and tarpaulins used during fumigation must be degassed and only then allowed to be moved and used. 
Conclusion

From the above we can conclude that for such an important technological operation for storage of grain and grain products as disinfection (fumigation) with the use of modern drugs, in Ukraine there is an appropriate legal framework, which currently requires and changes. But these changes need further improvement. Thus, the legislative deregulation that has taken place has led to the need to solve the following problems: the quality of control and control of fumigation processes, responsibility for the safe use of fumigants and the sale of counterfeit drugs on the market. The issue of special training (enshrined in law) for such work comes to the fore, which should be mandatory with the issuance of a permit in the form of a certificate and as well as an effective system of control by government agencies and business leaders themselves. Thus, the possibility of involving nonprofessional workers or dubious commercial structures, violations of sanitary-hygienic and ecological requirements in carrying out fumigation works will be excluded; minimized risks of accidents (poisonings); increased efficiency of disinfection and safety of grain products.

1. [Veb-sayt].URL:http://agro-business.com.ua/agro/zberihannia/item/13869-suchasni-sposoby-znezarazhuvannia-zerna-pidchas-dovhotryvaloho-zberihannia.html. Methods of grain disinfection.

2. [Veb-sayt]. URL: https://fermercentr.com/instrukciya-po-obezzarazhivaniyu-fumigacii-zerna-preparatami-fosfidaalyuminiyal. Instructions for disinfection (fumigation) of grain with phosphide-based drugs aluminium and magnesium.

3. [Veb-sayt]. URL: https://www.mnagor.com/ua/articles/40/. Fumigation is the main method of grain disinfection

4. [Veb-sayt]. URL: http://agroportal.ua/ua/news/rastenievodstvo/fumigatsiya-na-elevatore-doveryai-proverennym/. Elevator fumigation: trusts the tested.

5. [Veb-sayt]. URL: http://fumigacia.com.ua/. NGO "Fumigation Association".

6. [Veb-sayt]. URL: http://www.consumer.gov.ual. State Service of Ukraine for Food Safety and Consumer Protection.

7. [Veb-sayt]. URL: https://zakon.rada.gov.ua/laws/show/z1288-17. Rules of labor protection for workers engaged in work on storage and processing of grain (NPAOP 15.0-1.01-17).

8. [Veb-sayt]. URL: https://zakon.rada.gov.ua/laws/show/z1288-17. List of works with increased danger (NPAOP 0.00-4.122005).

9. [Veb-sayt]. URL: http://w1.c1.rada.gov.ua/pls/zweb2/webproc4 1?id=\&pf3511=67567. Draft Law on Amendments to Some Laws of Ukraine on Improving State Regulation in the Sphere of Pesticides and Agrochemicals.

10. [Veb-sayt]. URL: https://mineco.gov.ua/search/?s=державний реєстр пестииидів. State Register of Pesticides and Agrochemicals Permitted for Use in Ukraine

11. [Veb-sayt]. URL: https://chempedia.info Big Chemical Encyclopedia.

12. [Veb-sayt]. URL: Sekun M.P. Dovidnyk iz pestycydiv/V.M. Zherebko, O.M. Lapa-K.: Kolobig. - 2007. - 360 s.

13. [Veb-sayt]. URL: https://zakon.rada.gov.ua/laws/show/86/95-\%D0\%B2\%D1\%80. On Pesticides and Agrochemicals. Law of Ukraine (1995).

14. [Veb-sayt]. URL: https://zakon.rada.gov.ua/laws/show/180-14. On Plant Protection. Law of Ukraine (1998.)

15. [Veb-sayt]. URL: https://zakon0.rada.gov.ua/rada/show/v0001282-98. Transportation, storage and use of pesticides in the national economy. State sanitary rules (DCP 8.8.1.2.001-98).

16. [Veb-sayt]. URL: https://zakon.rada.gov.ua/laws/show/746-95-\%D0\%BF. Procedure for obtaining a permit (certificate) for the right to work related to transportation, storage, use and trade in pesticides and agrochemicals. Resolution of the Cabinet of Ministers of September 18, 1995 N 746.

О.О. Фесенко, канд. техн. наук, доцент, E-mail:fesenko_elena_@ukr.net

В.М. Лисюк, канд. техн. наук, доцент,

E-mail:vik-lis@ukr.net

С.М. Неменуща, канд. с-г. наук, ст. викладач, E-mail: s_nem_od@ukr.net

Одеська начіональна академія харчових технологій, вул. Канатна, 112, Одеса, 65039, Украӥна

\section{НОРМАТИВНО-ПРАВОВЕ ЗАБЕЗПЕЧЕННЯ ПРОЦЕСУ ЗНЕЗАРАЖЕННЯ ЗЕРНА НА ЗЕРНОПЕРЕРОБНИХ ОБ'ЄКТАХ}

\footnotetext{
Анотація

Стаття присвячена актуальній проблемі контролю забруднення зернових продуктів шкідниками сільського господарства на об'єктах зернопереробної галузі.

Автори висвітлюють застосування одного з найефективніших методів знезараження зернових продуктів - фумігаичію, яка, при умові грамотного та своєчасного проведення, дозволяє уникнути небажаних втрат запасів зерна та зернових продуктів.

Представлено характеристики основних хімічних речовин, які широко використовуються як фуміганти.

У статті узагальнено фуміганти, які застосовують у передових країнах світу та є альтернативою забороненому метилброміду.

Наведено стислий огляд сучасних фумігантів, дозволених законодавством Украӥни, розкрито існуючі проблеми внутрішнього ринку пестицидів.
} 
3 огляду на те, щуо ефективність фумігаиії залежить від дотримання технології фумігаційних робіт, у статті особлива увага приділяється процедурі дезінфекиії зернових продуктів фумігантами.

Автори детально аналізують нормативно-правову базу иъього питання, правила безпеки, використання засобів індивідуального захисту.

Виявлено характерні особливості та наслідки шкідливого впливу фумігантів на організм людини та навколишнє середовище в умовах зміни порядку дезінфекиії зернових продуктів.

На всіх підприємствах зернопереробної галузі пред'являються суворі вимоги безпеки для проведення робіт з фумігаuіï та дегазаиіï.

Підготовка досвідчених фахівців є однією із важливих передумов безпеки робіт по знезараженню, тому в даній статті запропоновано шляхи вирішення проблеми навчання кадрів.

Акцентовано увагу на необхідності вдосконалення нормативно-правових механізмів регулювання контролю якості фумігаиійних робіт.

Ключові слова: зернопереробна галузь, знезараження, фумігація, фуміганти, техніка безпеки.

\section{ЛITЕРАТУРА}

1. Способи знезараження зерна. [Електронний ресурс]. Режим доступу: http://agrobusiness.com.ua/agro/zberihannia/item/13869-suchasni-sposoby-znezarazhuvannia-zerna-pid-chas-dovhotryvalohozberihannia.html.

2. Інструкиія по знезараженню (фумігаиіi) зерна препаратами на основі фосфіду алюмінію та магнію. [Електронний ресурс]. Режим доступy: https://fermercentr.com/instrukciya-po-obezzarazhivaniyu-fumigacii-zerna-preparatamifosfida-alyuminiyal.

3. Фумігаиія - основний спосіб знезараження зерна. [Електронний ресурс]. Режим доступу: https://www.mnagor.com/ua/articles/40/.

4. Фумігаиія на елеваторі: довіряй перевіреним. [Електронний ресурс]. Режим доступу: http://agroportal.ua/ua/news/rastenievodstvo/fumigatsiya-na-elevatore-doveryai-proverennym/.

5. ВГО «Фумігаційна асоиіація». [Електронний ресурс]. Режим доступу: http://fumigacia.com.ua/.

6. Державна служба Украӥни з питань безпечності харчових продуктів та захисту споживачів. [Електронний ресурс]. Режим доступy: http://www.consumer.gov.ua/.

7. Правила охорони прачі для працівників, зайнятих на роботах зі зберігання та переробки зерна: НПАОП 15.0-1.0117. [Електронний ресурс]. Режим доступy: https://zakon.rada.gov.ua/laws/show/z1288-17.

8. Перелік робіт з підвищеною небезпекою: НПАОП 0.00-4.12-2005. [Електронний ресурс]. Режим доступу: https://zakon.rada.gov.ua/laws/show/z1288-17.

9. Проект Закону про внесення змін до деяких законів Украӥни щьоо вдосконалення державного регулювання у сфері поводження із пестицидами $i$ агрохімікатами. Режим доступу: http://w1.c1.rada.gov.ua/pls/zweb2/webproc4_1?id=\&pf3511=67567.

10. Державний реєстр пестицидів і агрохімікатів, дозволених до використання в Украӥні. [Електронний ресурс]. Режим достуny: https://mineco.gov.ua/search/?s=державний реєстр пестицидів.

11. Big Chemical Encyclopedia. [Електронний ресурс]. Режим доступy: https://chempedia.info/.

12. Секун М.П. Довідник із пестицидів / В.М. Жеребко, О.М. Лапа [та іни.] - К.: Колобіг. - 2007. - 360 c.

13. Закон Украйни «Про пестициди та агрохімікати» (1995р.). [Електронний ресурс]. Режим доступу: https://zakon.rada.gov.ua/laws/show/86/95-\%D0\%B2\%D1\%80.

14. Закон України «Про захист рослин» (1998р.). [Електронний ресурс]. Режим доступу: https://zakon.rada.gov.ua/laws/show/180-14.

15. Державні санітарні правила. Транспортування, зберігання та застосування пестищидів у народному господарстві: ДСП 8.8.1.2.001-98. [Електронний ресурс]. Режим доступу: https://zakon0.rada.gov.ua/rada/show/v0001282-98.

16. Порядок одержання допуску (посвідчення) на право роботи, пов'язаної з транспортуванням, зберіганням, застосуванням та торгівлею пестицидами і агрохімікатами. ППостанова КМУ від 18 вересня 1995 p. $N$ 746. [Електронний ресурс]. Режим доступy: https://zakon.rada.gov.ua/laws/show/746-95-\%D0\%BF.

\section{Received 21.05.2020 \\ Reviewed 30.07.2020}

\section{Revised 21.08.2020} Approved 28.08.2020

\section{Cite as Vancouver Citation Style}

Fesenko O., Lysyuk V., Nemenuscha S. Regulatory and legal provision of the process of disinfection of grain at grain processing facilities. Grain Products and Mixed Fodder's, 2020; 20 (3, 79): 4-9.

DOI

Cite as State Standard of Ukraine 8302:2015

Regulatory and legal provision of the process of disinfection of grain at grain processing facilities/ Fesenko O. et al. // Grain Products and Mixed Fodder's. 2020. Vol. 20, Issue 3 (79). P. 4-9.

DOI 